\title{
Low molecular weight activated protein $C$ inhibitors as a potential treatment for hemophilic disorders
}

Citation for published version (APA):

De Nanteuil, G., Gloanec, P., Beguin, S., Giesen, P. L. A., Hemker, H. C., Mennecier, P., Rupin, A., \& Verbeuren, T. J. (2006). Low molecular weight activated protein $C$ inhibitors as a potential treatment for hemophilic disorders. Journal of Medicinal Chemistry, 49(17), 5047-5050.

https://doi.org/10.1021/jm0606950

Document status and date:

Published: 25/07/2006

DOI:

10.1021/jm0606950

Document Version:

Publisher's PDF, also known as Version of record

\section{Please check the document version of this publication:}

- A submitted manuscript is the version of the article upon submission and before peer-review. There can be important differences between the submitted version and the official published version of record.

People interested in the research are advised to contact the author for the final version of the publication, or visit the DOI to the publisher's website.

- The final author version and the galley proof are versions of the publication after peer review.

- The final published version features the final layout of the paper including the volume, issue and page numbers.

Link to publication

\footnotetext{
General rights rights.

- You may freely distribute the URL identifying the publication in the public portal. please follow below link for the End User Agreement:

www.umlib.nl/taverne-license

Take down policy

If you believe that this document breaches copyright please contact us at:

repository@maastrichtuniversity.nl

providing details and we will investigate your claim.
}

Copyright and moral rights for the publications made accessible in the public portal are retained by the authors and/or other copyright owners and it is a condition of accessing publications that users recognise and abide by the legal requirements associated with these

- Users may download and print one copy of any publication from the public portal for the purpose of private study or research.

- You may not further distribute the material or use it for any profit-making activity or commercial gain

If the publication is distributed under the terms of Article $25 \mathrm{fa}$ of the Dutch Copyright Act, indicated by the "Taverne" license above, 


\section{Low Molecular Weight Activated Protein C Inhibitors as a Potential Treatment for Hemophilic Disorders}

Guillaume De Nanteuil,*, ${ }^{\text {P }}$ Philippe Gloanec,, Suzette Béguin," Peter L. A. Giesen," H. Coenraad Hemker," Philippe Mennecier, ${ }^{\dagger}$ Alain Rupin,${ }^{\dagger}$ and Tony J. Verbeuren ${ }^{\dagger}$

\begin{abstract}
Division D of Medicinal Chemistry and Division of Angiology, Institut de Recherches Servier, 11 Rue des Moulineaux, 92150 Suresnes, France, and Synapse b.v., Cardiovascular Research Institute Maastricht, University of Maastricht, P.O. Box 616, 6200 MD Maastricht, The Netherlands
\end{abstract}

Received June 9, 2006

Abstract: The synthesis and evaluation of inhibitors of activated protein $\mathrm{C}(\mathrm{aPC})$ are reported. This serine protease is partly responsible for the degradation of factor VIIIa, involved in the regulation of bleeding in hemophilia A. Benzamidine-containing derivatives were found to be potent aPC inhibitors, some of them showing selectivity against the procoagulant protease thrombin. Moreover, compound $\mathbf{1}$ significantly restored the generation of thrombin in hemophiliac plasma.

Hemophilia A is a severe inherited disorder characterized by an increased bleeding tendency. The incidence of the disease in humans is estimated at 1 in 5000. The major symptom of hemophilia is hemarthrosis located at the major articulations, most of the time degenerating to chronic arthropathy, which is characterized by severe degeneration of the cartilagineous tissues and subchondral bone. Other types of bleeding can also occur in the muscles and the kidney and intracerebrally, this latter situation being an important cause of mortality. ${ }^{1}$

Bleeding tendency in hemophilia $\mathrm{A}$ is correlated with a defect in the levels or in the functionality of factor (F) VIII. Patients with less than $1 \%$ of the normal level are considered severe hemophiliacs. Those with $1-5 \%$ are considered moderate, and those with $5-25 \%$ are considered mild. ${ }^{1}$ FVIII is cleaved by thrombin to activated FVIII (FVIIIa). FVIIIa plays a major role in the intrinsic pathway of the coagulation cascade where it is responsible through formation of the tenase complex FVIIIaFIXa for the amplification of the initiation signal ascribed to the extrinsic, tissue-factor-dependent pathway, ultimately leading to the generation of procoagulant thrombin.

Current treatments for the hemophiliac patient are mainly composed of FVIII concentrates; dramatic progress in the purification and virus inactivation procedures has allowed the preparation of human-derived FVIII and recombinant FVIII. Although these two sources of FVIII have similar pharmacokinetic and clinical properties, the major drawback in the utilization of FVIII concentrates is the development of inhibitory antibodies in up to $25 \%$ of hemophilia A patients, who develop bleeding tendencies unresponsive to FVIII infusions. ${ }^{2}$

It has been shown that the severity of the disease could be dramatically decreased, even with a modest elevation of

* To whom correspondence should be addressed. Phone: +3315572 22 34. Fax: +33 1557224 30. E-mail: guillaume.denanteuil@fr.netgrs.com.

$\S$ Division D of Medicinal Chemistry, Institut de Recherches Servier.

\# University of Maastricht,.

† Division of Angiology, Institut de Recherches Servier. circulating FVIII levels of 2-5\%. This would also decrease the amount of FVIII necessary to regulate the bleeding tendencies and, as a consequence, the development of resistance mechanism to FVIII.

Activated protein $\mathrm{C}(\mathrm{aPC})$ is a trypsin-like serine protease synthesized from protein $\mathrm{C}$ through activation by thrombomodulin-bound thrombin. aPC enzymatic activity requires the presence of a cell surface, calcium ions, and a cofactor protein $\mathrm{S}$ (PS), which potentiates the cleavage by aPC of its two main substrates, FVa and FVIIIa. ${ }^{3}$

The concept of using aPC inhibitors as procoagulant agents has been mentioned by Butenas in 199. In an experiment mimicking hemophilia $\mathrm{A}$, the authors showed that thrombin generation was barely detectable, while in the presence of the pseudopeptidic inhibitors Arg-ANSN-Lys(Z)-Lys(Z)-OBz (ANSN = 6-aminonaphthalene-2-sulfonyl) and Lys-Lys-Thr-Arg-ANSNLys(Z)-Lys(Z)-OBz, the absence of FVIII was fully compensated. aPC inhibition was said to be responsible for an increased generation of thrombin. ${ }^{4}$ Thus, potent inhibitors of aPC devoid of inhibitory properties against procoagulant proteases such as thrombin (Thr) represent structural targets able to improve thrombin generation. Herein, we report for the first time the discovery of a new class of benzamidine-containing aPC inhibitors and show that some of these compounds are able to increase the physiological levels of thrombin in human hemophiliac plasma.

In the course of our quest for novel anticoagulants, all the compounds prepared were counterscreened against aPC. ${ }^{5}$ Compound 1 was found to be a potent inhibitor of aPC, with an $\mathrm{IC}_{50}$ of $823 \mathrm{nM}$. In addition, 1 showed promising selectivity against thrombin with an $\mathrm{IC}_{50}$ around $47 \mu \mathrm{M}$.

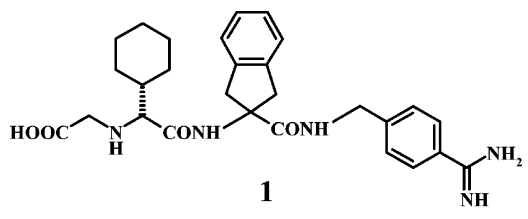

The synthesis of $\mathbf{1}$ is shown in Scheme 1 and is representative of the preparation of all the compounds described here. It was accomplished in six steps starting from the commercially available amino ester 2, which was coupled with Boc- $(R)$ cyclohexylglycine to give the dipeptidic intermediate 3 in $97 \%$ yield. Saponification of the C-terminal ester with sodium hydroxide in dioxane (95\%) was followed by coupling with protected aminomethylbenzamidine ${ }^{6}$ to give $\mathbf{4}$ in $84 \%$ yield. Deprotection of the N-terminal amino group under acidic conditions was realized in $95 \%$ yield and was followed by alkylation with benzyl bromoacetate in a nonoptimized yield of $54 \%$ to afford $\mathbf{5}$. Finally, a double deprotection was performed by hydrogenolysis to give the desired compound in $66 \%$ yield.

To improve the activity and selectivity profiles of $\mathbf{1}$, structural modifications at the different subsites were considered. We started by replacing $(R)$-cyclohexylglycine at the $\mathrm{P} 3$ subsite by other simple amino acids (named as $\mathrm{A}$ ); the corresponding $\mathrm{IC}_{50}$ values for aPC and thrombin are given in Table 1.

The $(R)$-configuration for this amino acid appeared to be critical for optimum potency because the $(S)$-cyclohexylglycine 
Scheme 1. Synthetic Route to Compound $\mathbf{1}^{a}$

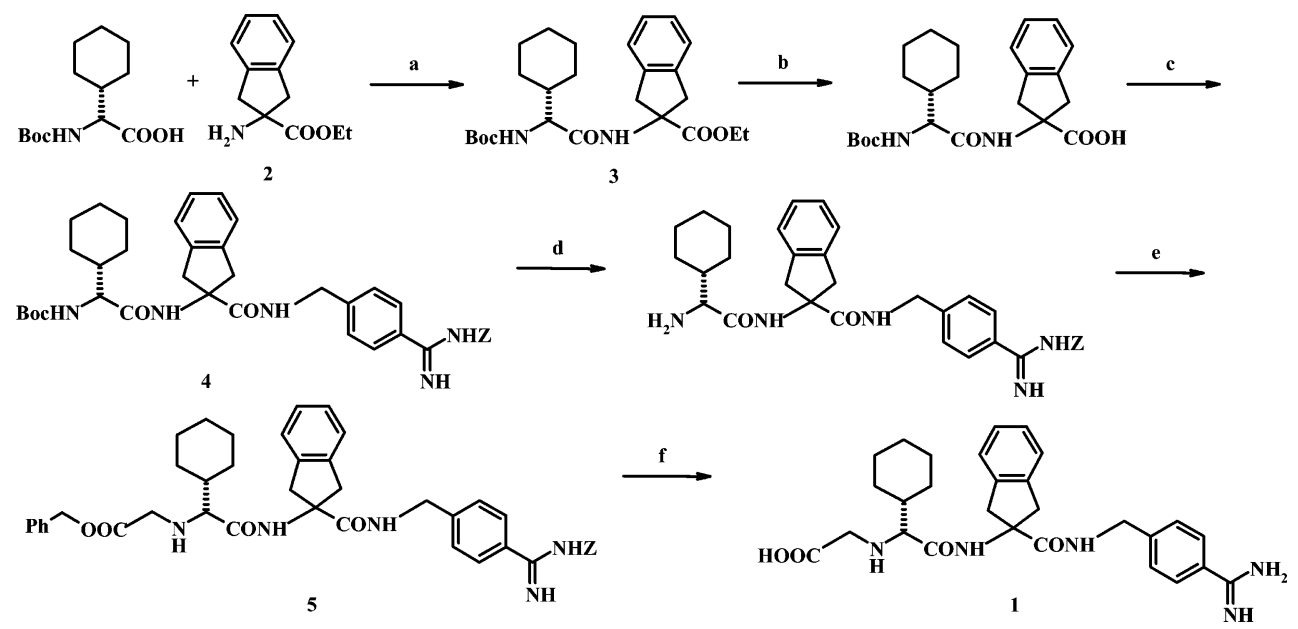

${ }^{a}$ Reaction conditions: (a) HOBT, TBTU, DIEA, DMF, 97\%; (b) NaOH, dioxane, 95\%; (c) protected aminomethylbenzamidine, DIEA-EDCI, DMF, $84 \%$; (d) $\mathrm{HCl}$, dioxane- $\mathrm{CH}_{2} \mathrm{Cl}_{2}, 95 \%$; (e) aqueous saturated $\mathrm{NaHCO}_{3}-\mathrm{EtOAc}$, then $\mathrm{BrCH}_{2} \mathrm{COOCH}_{2} \mathrm{Ph}, \mathrm{K}_{2} \mathrm{CO}_{3}, \mathrm{CH}_{3} \mathrm{CN}, 54 \%$; (f) $\mathrm{H}_{2}, \mathrm{Pd}-\mathrm{C}, \mathrm{CH}_{3} \mathrm{OH}$, $86 \%$.

Table 1. aPC and Thrombin Inhibition Values for Compounds with Modified Amino Acids at the P3 Subsite

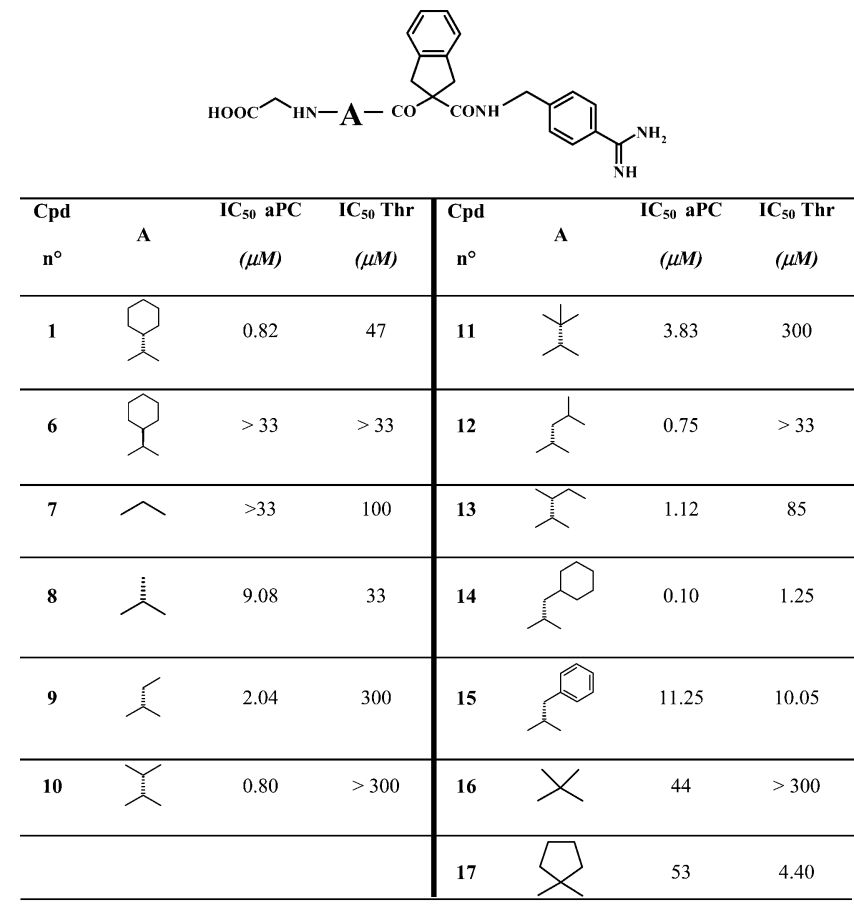

containing analogue 6 was totally devoid of activity. The glycine derivative 7 was also completely inactive. Conversion of cyclohexylglycine to alanine or ethylglycine $(\mathbf{8}$ or $\mathbf{9})$ led to a loss of potency with $\mathrm{IC}_{50}$ greater than $1 \mu \mathrm{M}$. In contrast, medium-sized amino acids such as valine (10) or leucine (12) restored the inhibitory activity with $\mathrm{IC}_{50}$ against aPC of 0.80 or $0.75 \mu \mathrm{M}$, respectively. Interestingly, $\mathbf{1 0}$ was found to be at least 1 order of magnitude more selective than $\mathbf{1}$ or $\mathbf{1 2}$ with an $\mathrm{IC}_{50}$ against thrombin greater than $300 \mu \mathrm{M}$.

Further increases in the size of the amino acid side chain with a tert-butylglycine (11) or an isoleucine (13) were again deleterious for activity.

Replacement of cyclohexylglycine with cyclohexylalanine gave 14, the most potent aPC inhibitor of this first series of compounds with an $\mathrm{IC}_{50}$ of $0.10 \mu \mathrm{M}$; unfortunately, inhibition of thrombin with $\mathbf{1 4}$ was also enhanced with an $\mathrm{IC}_{50}$ value in the micromolar range. In contrast, the aromatic analogue $\mathbf{1 5}$
Table 2. aPC and Thrombin Inhibition Values for Compounds with Modified Amino Acids at the P2 Subsite ${ }^{a}$

(1)

${ }^{a}$ The asterisk $(*)$ represents monosubstitution on the $\alpha$-carbon.

was much less active. Finally, introduction of 1-aminoisobutyric acid in $\mathbf{1 6}$ or 1-aminocyclopentane carboxylic acid in $\mathbf{1 7}$ gave inactive derivatives.

Taking these first results into account, we maintained $(R)$ valine as the $\mathrm{N}$-terminal amino acid to study the influence of the central amino acid located at the P2 subsite (named as B in Table 2). 2-Aminoindane-2-carboxylic acid used in $\mathbf{1 0}$ was replaced by several structural analogues; dimethoxy substitution on the phenyl ring of the indane nucleus (18) led to an important drop in activity. Introduction of a nitrogen atom at position 4 


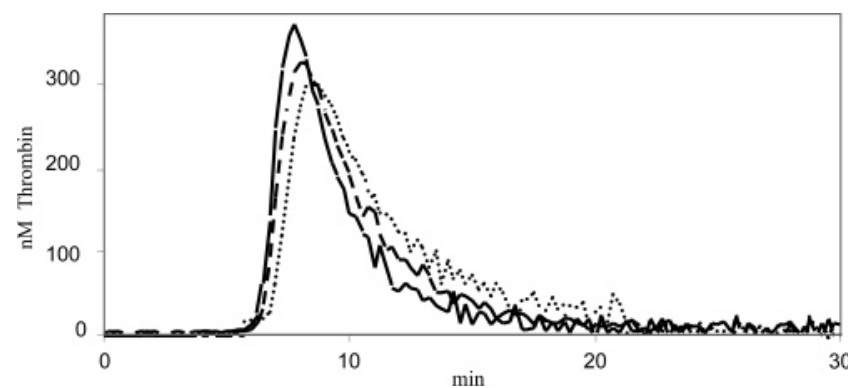

Figure 1. Thrombin generation with increasing concentrations of 1 $((-) 0 \mathrm{nM},(--) 10 \mathrm{nM},(\cdots) 20 \mathrm{nM})$ in PPP from a normal volunteer.

in the indane ring gave two diastereomers $\mathbf{1 9}$ and $\mathbf{2 0}$ that could be separated. This was not the case with $\mathbf{2 1}$ with the nitrogen atom at position 5 in the indane ring. These three compounds gave micromolar values for aPC inhibition. Introduction of a second aromatic ring in a cyclopenta $[a]$ - or cyclopenta $[b]$ naphthalene system gave $\mathbf{2 2}$ or $\mathbf{2 3}$, respectively. The former was found to be a potent $\mathrm{aPC}$ inhibitor with an $\mathrm{IC}_{50}$ of 0.25 $\mu \mathrm{M}$ but was not selective vs thrombin, while the latter was much less active with an $\mathrm{IC}_{50}$ around $10 \mu \mathrm{M}$.

Increasing the size of the central amino acid by using 2-amino-2,3-dihydro-1H-phenalene-2-carboxylic acid gave inhibitor 24, almost twice as potent as $\mathbf{1 0}$ and with a similar impressive selectivity profile. The 6-amino-6,7-dihydro-5 $\mathrm{H}$ dibenzo[a,c]cycloheptene-6-carboxylic acid containing 25 was much less active with an $\mathrm{IC}_{50}$ greater than $10 \mu \mathrm{M}$. Potency was also improved by extruding the indane ring from the amino acid skeleton to give 26. This compound was also very selective with an $\mathrm{IC}_{50}$ against thrombin greater than $33 \mu \mathrm{M}$. Using $(S)$ phenylalanine in $\mathbf{2 7}$ proved to be an interesting variation with an inhibition value for aPC similar to that of $\mathbf{1}$, albeit with a decrease in selectivity. Introducing a second phenyl ring gave diphenylalanine containing $\mathbf{2 8}$, which was completely devoid of inhibitory activity.

As a summary of these preliminary investigations, it is worth noting that the best compromise between inhibitory potency for aPC and selectivity against thrombin was obtained by using a medium-sized amino acid at P3 (e.g., valine). As far as P2 was concerned, the simple indane ring remained the favored moiety mostly because of its easy synthetic access either as a spiro system such as in $\mathbf{1 0}$ or as a substituent on the $\alpha$-carbon in $\mathbf{2 6}$. Because of its improved selectivity vs thrombin, 24 containing a central tricyclic system was also selected as an interesting candidate for further studies.

As a preliminary indication that an aPC inhibitor might be of interest as a potential treatment for hemophilia disorders, 1 was studied on thrombin generation using the calibrated automated thrombogram assay. ${ }^{7}$ In normal pooled human platelet poor plasma (PPP), ${ }^{8}$ thrombin generation induced by intrinsic coagulation pathway was observed with peak levels around $400 \mathrm{nM}$. Under these conditions, inhibitor 1 barely increased thrombin generation when incubated at increasing concentrations of 10 and $20 \mathrm{nM}$ (Figure 1). In contrast, in a human moderate hemophilia A PPP (FVIII < 5\%), where thrombin generation was almost absent (Figure 2), inhibitor $\mathbf{1}$ used at 10 and $20 \mathrm{nM}$ significantly restored the thrombin generation to a maximum level of $160 \mathrm{nM}$.

Moreover, in human severe hemophilia A PPP spiked with $5 \%$ normal human PPP where the thrombin generation peak was at $55 \mathrm{nM}$, inhibitor $\mathbf{1}(20 \mathrm{nM})$ increased thrombin generation to a maximum peak level of $201 \mathrm{nM}$. Notably, since $\mathrm{IC}_{50}$ of $\mathbf{1}$ in the screening assay $(0.82 \mu \mathrm{M})$ is far above the concentration that gives a maximal effect in the thrombin generation assay

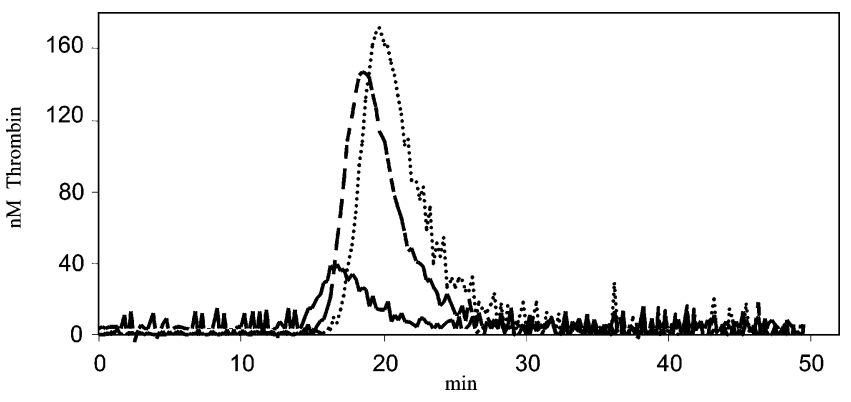

Figure 2. Thrombin generation with increasing concentrations of $\mathbf{1}$ $\left((-) 0 \mathrm{nM},(--)^{-)} 10 \mathrm{nM},(\cdots) 20 \mathrm{nM}\right)$ in PPP from hemophiliac patients.

$(20 \mathrm{nM})$, it is suggested that the inhibitory efficacy of $\mathbf{1}$ on aPC is higher in the presence of its physiological substrate than with its synthetic chromogenic substrate.

In summary, we have reported here the preparation and biochemical evaluation of potent low molecular weight inhibitors of activated protein $\mathrm{C}$, some of them showing a promising selectivity against the procoagulant protease thrombin. In a thrombin generation assay, inhibitor $\mathbf{1}$ was shown to be inactive in normal human plasma while it significantly restored thrombin generation in hemophilia A plasma. Since compounds described here contain a hydrophilic benzamidine moiety, prodrugs similar to those obtained from melagatran ${ }^{9}$ or dabigatran ${ }^{10}$ in the field of thrombin inhibition will have to be prepared to obtain orally available inhibitors. On the basis of these preliminary results, it appears here for the first time that a low molecular weight selective inhibitor of aPC could become a potential oral treatment of great value for increasing FVIII levels in hemophiliacs, thus improving the quality of life of people enduring this devastating genetic disease.

Acknowledgment. The authors acknowledge the skillful technical assistance in medicinal chemistry of Camille Poindron, Sophie Cornet, and Christian Mériaux. They also thank Dr. JeanPaul Bouchet and his group for analytical and spectral determinations.

Supporting Information Available: Synthetic procedures; spectral and elemental analysis data for the tested compounds; and experimental protocols for aPC, thrombin inhibition, and thrombin generation. This material is available free of charge via the Internet at http://pubs.acs.org.

\section{References}

(1) Klinge, J.; Ananyeva, N. M.; Hauser, C. A. E.; Saenko, E. L. Hemophilia A. From Basic Science to Clinical Practice. Semin. Thromb. Hemostasis 2002, 28, 309-321.

(2) Bishop, P.; Lawson, J. Recombinant Biologics for Treatment of Bleeding Disorders. Nat. Rev. Drug Discovery 2004, 3, 684-694.

(3) Kraus, M. The Anticoagulant Potential of the Protein C System in Hereditary and Acquired Thrombophilia: Pathomechanisms and New Tools for Assessing Its Clinical Relevance. Semin. Thromb. Hemostasis 1998, 24, 337-354.

(4) Butenas, S.; Mann, K. Peptidomimetics Containing 6-Peptidylamino1-Naphthalenesulfonamide Moieties. World Patent WO 98/22125, 1998.

(5) Activity of the compounds was evaluated by determining the concentrations that inhibit by $50 \%$ the proteasic action of aPC against the chromogenic substrate Pyroglu-Pro-Arg-pNA (S-2366, Chromogenix) ( $\mathrm{IC}_{50}$ expressed in $\left.\mu \mathrm{M}\right)$. Selectivity was evaluated by comparing this $\mathrm{IC}_{50}$ value with that obtained against thrombin in the presence of its natural substrate, fibrinogen (Enzyme Research Laboratories).

(6) Lila, C.; Gloanec, P.; Cadet, L.; Hervé, Y.; Fournier, J.; Leborgne, F.; Verbeuren, T. J.; De Nanteuil, G. Large Scale Preparation of Protected 4-Aminomethylbenzamidine. Application to the Synthesis of the Thrombin Inhibitor Melagatran. Synth. Commun. 1998, 28, 4419-4429. 
(7) Hemker, H. C.; Giesen, P.; Al Dieri, R.; Regnault, V.; de Smedt, E.; Wagenvoord, R.; Lecompte, T.; Béguin, S. The Calibrated Automated Thrombogram (CAT): A Universal Routine Test for Hyper and Hypocoagulability. Pathophysiol. Haemostasis Thromb. 2002, 32, 249-253.

(8) Hemker, H. C.; Giesen, P.; Al Dieri, R.; Regnault, V.; de Smedt, E.; Wagenvoord, R.; Lecompte, T.; Béguin, S. Calibrated Automated Thrombin Generation Measurement in Clotting Plasma. Pathophysiol. Haemostasis Thromb. 2003, 33, 4-15.

(9) Gustafsson, D.; Nyström, J.-E.; Carlsson, S.; Bredberg; U.; Eriksson, U.; Gyzander, E.; Elg, M.; Antonsson, T.; Hoffmann, K.-J.; Ungell,
A.-L.; Sörensen, H.; Någård, S.; Abrahamsson, A.; Bylund, R. The Direct Thrombin Inhibitor Melagatran and Its Oral Prodrug H 376/ 95: Intestinal Absorption Properties, Biochemical and Pharmacodynamic Effects. Thromb. Res. 2001, 101, 171-181.

(10) Hauel, N. H.; Nar, H.; Priepke, H.; Ries, U.; Stassen, J.-M.; Wienen, W. Structure-Based Design of Novel Potent Nonpeptide Thrombin Inhibitors. J. Med. Chem. 2002, 45, 1757-1766.

\section{JM0606950}

